\title{
Morphoagronomic characterization and genetic diversity of a common bean RIL mapping population derived from the cross Rudá x AND 277
}

L.C. Silva ${ }^{1}$, R.O. Batista ${ }^{1}$, R.S.R. Anjos ${ }^{1}$, M.H. Souza ${ }^{2}$, P.C.S. Carneiro ${ }^{3}$, T.L.P.O. Souza ${ }^{4}$ E.G. Barros ${ }^{5}$ and J.E.S. Carneiro ${ }^{2}$

${ }^{1}$ Programa de Pós-Graduação em Genética e Melhoramento, Universidade Federal de Viçosa, Viçosa, MG, Brasil

${ }^{2}$ Departamento de Fitotecnia, Universidade Federal de Viçosa, Viçosa, MG, Brasil

${ }^{3}$ Departamento de Biologia Geral, Universidade Federal de Viçosa, Viçosa, MG, Brasil

${ }^{4}$ Embrapa Arroz e Feijão, Santo Antônio de Goiás, GO, Brasil

${ }^{5}$ Programa de Pós-Graduação em Ciências Genômicas e Biotecnologia,

Universidade Católica de Brasília, Brasília, DF, Brasil

Corresponding author: L.C. Silva

E-mail: leocalvino@yahoo.com.br

Genet. Mol. Res. 15 (3): gmr.15038112

Received November 19, 2015

Accepted May 31, 2016

Published July 29, 2016

DOI http://dx.doi.org/10.4238/gmr.15038112

Copyright $(2016$ The Authors. This is an open-access article distributed under the terms of the Creative Commons Attribution ShareAlike (CC BY-SA) 4.0 License.

ABSTRACT. Recombinant inbred lines (RILs) are a valuable resource for building genetic linkage maps. The presence of genetic variability in the RILs is essential for detecting associations between molecular markers and loci controlling agronomic traits of interest. The main goal of this study was to quantify the genetic diversity of a common bean 
RIL population derived from a cross between Rudá (Mesoamerican gene pool) and AND 277 (Andean gene pool). This population was developed by the single seed descent method from $500 \mathrm{~F}_{2}$ plants until the $\mathrm{F}_{10}$ generation. Seven quantitative traits were evaluated in the field in 393 RILs, the parental lines, and five control cultivars. The plants were grown using a randomized block design with additional controls and three replicates. Significant differences were observed among the RILs for all evaluated traits $(\mathrm{P}<0.01)$. A comparison of the RILs and parental lines showed significant differences $(\mathrm{P}<0.01)$ for the number of days to flowering (DFL) and to harvest (DH), productivity (PROD) and mass of 100 beans (M100); however, there were no significant differences for plant architecture, degree of seed flatness, or seed shape. These results indicate the occurrence of additive $\mathrm{x}$ additive epistatic interactions for DFL, DH, PROD, and M100. The 393 RILs were shown to fall into 10 clusters using Tocher's method. This RIL population clearly contained genetic variability for the evaluated traits, and this variability will be crucial for future studies involving genetic mapping and quantitative trait locus identification and analysis.

Key words: Genetic diversity; Recombinant inbred lines; Transgressive segregation; Epistatic interactions; Mapping population; Phenotypic characterization

\section{INTRODUCTION}

Productivity and production of the common bean (Phaseolus vulgaris L.) in Brazil is limited by planting systems and by factors such as distribution, product marketing, and regional preferences. In terms of plant-related factors, susceptibility to pests and diseases, tolerance to lodging, inadequate plant architecture, efficiency of nitrogen biological fixation, nutrient absorption, sensitivity to drought and high temperatures, and nutritional and culinary quality of the crop have been highlighted (Barros and Souza, 2012). Many of these latter limiting factors might be minimized by genetic-based plant breeding.

A promising approach for breeding is DNA marker-assisted selection. The advantages of the use of molecular markers for common bean breeding programs are that they are virtually unlimited in number, easy to detect, behave like simple traits with a predictable inheritance mode, and are not affected by the environment (Collard et al., 2005). Genetic mapping of the positions of markers and the distances between them on chromosomes can be used to produce a linkage map. Such maps are invaluable for identifying chromosomal regions containing genes and quantitative trait loci (QTLs) related to traits of agronomic interest.

Different types of population are used for genetic mapping in plants, each with its particular strengths and limitations, such as $F_{2}$ generations, populations derived by selffertilization of the $\mathrm{F}_{2}$ generation, recombinant inbred lines (RILs), double-haploid populations generated by crossing (Schuster and Cruz, 2004), and nearly isogenic lines (Semagn et al., 2006).

The common bean is a diploid legume $(2 \mathrm{n}=2 \mathrm{x}=22)$ with a relatively small genome that contains $0.66 \mathrm{pg}$ of DNA per haploid genome and corresponds to $6.33 \times 10^{8} \mathrm{bp}$ (Arumugahathan and Earle, 1991). Lamprecht (1961) produced the first published genetic

Genetics and Molecular Research 15 (3): gmr.15038112 
map for common beans, thereby initiating the work of genetic mapping in this crop.

A population of 75 RILs obtained from a cross between BAT 93 (Mesoamerican) and Jalo EPP 558 (Andean) (Freyre et al., 1998) has frequently been used for genetic mapping studies in common bean; this group of RILs is generally named the BJ population. Grisi et al. (2007) used microsatellite markers to construct the first linkage map of the BJ population. However, the relatively small size of this population drastically affects the accuracy of the estimates of recombination rates and, consequently, the precision of the resulting genetic maps. To circumvent this problem, Embrapa Arroz e Feijão (Santo Antônio de Goiás, GO) crossed BAT 93 and Jalo EPP 558 to obtain a greater number of RILs, and raised the population size to approximately 200 RILs (Barros and Souza, 2012). However, maintenance and multiplication of these RILs have not been effective due to their poor adaptation to Brazilian soil and climatic conditions, which has compromised the effective size of this population for genetic mapping and QTL analysis.

The International Center for Tropical Agriculture (CIAT, Cali, Colombia) developed a population composed of 87 RILs from a cross between DOR 346 (Mesoamerican) and G 19833 (Andean), and this population has also been widely used for genetic mapping (Blair et al., 2003; Galeano et al., 2009). Currently, however, seeds of these RILs are not readily available. Another mapping population was developed by Blair et al. (2012) and comprises 113 RILs derived from a cross between DOR 364 and BAT 447; both parents belong to the Mesoamerican gene pool. The small size of this population is a limitation; moreover, the availability of seeds for exchange and use by different teams is low.

Based on a simulation, Silva et al. (2007) estimated that populations of 200, 300, and 500 RILs are required for obtaining reliable maps with high, medium and low saturation levels, respectively. These saturation levels would correspond to 5,10 , and $20 \mathrm{cM}$ between markers, respectively.

In this context, the Common Bean Breeding Program of the Federal University of Viçosa (UFV) developed a RIL population containing approximately 500 lines. This population was derived from a cross between Rudá (Mesoamerican) and AND 277 (Andean) and is currently at the $\mathrm{F}_{10}$ generation (Sanglard et al., 2013). This is a promising RIL population because it derives from parents of contrasting gene pools. The main goal of the present study was to quantify the genetic diversity of the Rudá x AND 277 RIL mapping population using seven traits of agronomic importance.

\section{MATERIAL AND METHODS}

\section{Plant material}

An RIL population of approximately 500 lines was obtained using the single seed descent (SSD) method from a cross between the cultivar Rudá (Mesoamerican) and AND 277 (Andean) (Sanglard et al., 2013). In the present study, we used 393 of these RILs that had produced enough seeds to be evaluated in field trials. The Rudá cultivar was developed at CIAT from a cross between cultivars Carioca and Rio Tibagi. It was introduced into Brazil as line A285 by Embrapa Arroz e Feijão (Embrapa, 2014).

Rudá has carioca type beans, the commercial grade that is most consumed in Brazil ( $70 \%$ of the market). This cultivar was used by UFV Bean Plant Improvement Program as the recurring parent in backcross programs to develop disease resistance. This program produced

Genetics and Molecular Research 15 (3): gmr.15038112 
various isolines that have different combinations of genes resistant to anthracnose, rust, and angular leaf spot, fungal diseases caused by Colletotrichum lindemuthianum, Uromyces appendiculatus, and Pseudocercospora griseola, respectively. In addition, the program was used to develop disease resistant isolines with carioca beans using a molecular markerassisted pyramiding approach. AND 277 (Andean) was also developed at CIAT by the crosses [Cargabello x (Pompadour Checa x Linea 17)] x (Linea 17 x Red Cloud). This cultivar has resistance to angular leaf spot (Aggarwal et al., 2004).

\section{Morphoagronomic characterization}

The field tests for agronomic evaluation of the 393 RILs were conducted during the irrigated growing season (August to November) in 2012 at UFV Experimental Station $\left(20^{\circ} 50^{\prime} 30^{\prime \prime} \mathrm{S}, 42^{\circ} 48^{\prime} 30^{\prime \prime} \mathrm{W}\right.$, and altitude $\left.720 \mathrm{~m}\right)$. The plants were grown in a $20 \times 20$ triple lattice design, with the 400-plant block comprising 393 RILs, the parental cultivars Rudá and AND 277, and five control cultivars (Pérola, BRSMG Madrepérola, MRS Estilo, BRSMG Majestoso, and RP-1). Each experimental plot was composed of 30 plants, distributed into two rows of $1.0 \mathrm{~m}$ each, with $0.5 \mathrm{~m}$ between the rows and 15 plants in each row. Agronomic traits were evaluated according to the "Minimum Bean Descriptors (P. vulgaris L.)" proposed by Serviço Nacional de Proteção de Cultivares of Ministério da Agricultura Pecuária e Abastecimento (MAPA, 2012). The following traits were evaluated: number of days to flowering (DFL), which was defined as the period from emergence of at least $50 \%$ of the plants in the plot to the time when at least $50 \%$ of the plants had at least one fully open flower; number of days until harvest (DH), or cycle, defined as the time from emergence of at least 50\% plants in the plot until at least $90 \%$ of the pods were dry; productivity (PROD) $(\mathrm{kg} / \mathrm{ha})$, which corresponds to the amount of beans $(\mathrm{g})$ harvested in each plot in relation to the area of land $\left(1.0 \mathrm{~m}^{2}\right)$; weight of 100 beans (M100), which corresponds to the weight of 100 beans sampled randomly from each plot; degree of flattening $(\mathrm{H})$ and shape of bean $(\mathrm{J})$, measured in five beans from each plot using the criteria of Puerta Romero quoted by MAPA (2012), which indicate the relationship between the thickness and width of the bean and the bean length and width, respectively. Plant architecture (ARQ) was evaluated when the plants in each plot had matured; the assessment was performed using the criteria described by Collicchio et al. (1997).

\section{Statistical analysis}

The data on the traits DFL, DH, ARQ, PROD, H, J, and M100 were subjected to analysis of variance according to the model for the triple lattice $20 \times 20$. The data were also analyzed in randomized blocks design with additional cultivar controls, i.e., 393 RILs and two controls (the parents, Rudá and AND 277), based on the model:

$$
\mathrm{Y}_{\mathrm{ij}}=\mu+\mathrm{t}_{\mathrm{i}}+\mathrm{b}_{\mathrm{j}}+\mathrm{e}_{\mathrm{ij}}
$$

where: $\mathrm{Y}_{\mathrm{ij}}=$ observation concerning the treatment $i$ in block $j ; \mu=$ overall average; $\mathrm{t}_{\mathrm{i}}=$ effect of the $i^{t h}$ treatment $[i=1,2, \ldots,(\mathrm{g}+t e)=\mathrm{T}]$, and $g$ is the number of genotypes/strains $(g=393)$ and the number of controls/parents $(t e=2)$, both considered as random effects; $b_{\mathrm{j}}=$ effect of block $j(j=1,2$ e 3$)$; bj $\sim \operatorname{NID}\left(0, \sigma_{b}^{2}\right)$; $\mathrm{e}_{\mathrm{ij}}=$ random error, eij $\sim \operatorname{NID}\left(0, \sigma^{2}\right)$.

Genetics and Molecular Research 15 (3): gmr.15038112 
The scheme for the analysis of variance with the sources of variation, degrees of freedom, sum of squares, mean squares, mean squares expectations, and $\mathrm{F}$ test are presented in Table 1. The average of each RIL for the evaluated traits was compared with the average of each cultivar control (parent) using the Dunnett test at 5\% probability. The averages of the 395 genotypes were assessed for clustering using the Scott-Knott test at the 5\% probability level.

For the analysis of genetic diversity in the 395 genotypes, the Mahalanobis generalized distance was used as a measure of dissimilarity and, subsequently, the genotypes were analyzed for clustering by Tocher's method. The relative importance of the traits for genetic dissimilarities among the RILs was determined according to Singh (1981). All analyses were performed using the program "Genes" (Cruz, 2013).

Table 1. Scheme of analysis of variance and mean squares expectations for the model in blocks with additional witnesses, used for the analysis of the trial of morphoagronomic characterization of RILs (Rudá x AND 277). Coimbra, MG, winter 2012.

\begin{tabular}{|c|c|c|c|c|c|}
\hline $\mathrm{SV}^{1}$ & d.f. ${ }^{2}$ & $\mathrm{SS}^{3}$ & $\mathrm{MS}^{4}$ & $\mathrm{M}(\mathrm{EE})^{5}$ & $\mathrm{~F}^{6}$ \\
\hline Blocks & $r-1$ & SQB & QMB & $\sigma^{2}+\left(\mathrm{g}+\mathrm{t}_{\mathrm{e}}\right) \sigma_{\mathrm{b}}^{2}$ & - \\
\hline Treatments & $(\mathrm{g}+\mathrm{te})-1$ & SQT & QMT & $\sigma^{2}+\sigma^{2} t$ & QMT/QMR \\
\hline Genotypes (G) & $g-1$ & SQG & QMG & $\sigma^{2}+\sigma^{2} g$ & QMG/QMR \\
\hline Witnesses $(\mathrm{Te})$ & te -1 & SQTe & QMTe & $\sigma^{2}+\sigma_{\mathrm{te}}^{2}$ & $\mathrm{QMTe} / \mathrm{QMR}$ \\
\hline $\mathrm{G} v s \mathrm{Te}$ & 1 & SQGr & QMGr & - & $\mathrm{QMGr} / \mathrm{QMR}$ \\
\hline Error & $(\mathrm{r}-1)(\mathrm{T}-1)$ & $\mathrm{SQR}$ & QMR & $\sigma^{2}$ & - \\
\hline Total & $\mathrm{r}(\mathrm{T}-1)$ & SQTo & - & - & - \\
\hline
\end{tabular}

${ }^{1}$ Sources of variation (SV), ${ }^{2}$ degrees of freedom (d.f.), ${ }^{3}$ sum of squares (SS), ${ }^{4}$ mean squares (MS), ${ }^{5}$ mean squares expectations $[\mathrm{M}(\mathrm{EE})]$, and ${ }^{6} \mathrm{~F}$ test.

\section{RESULTS}

A summary of the outcome of analyses of variance and of the estimates of the efficiency of the lattice are presented in Table 2. The efficiency of the lattice was low, at most $105.16 \%$, that suggested that the analysis by randomized blocks model with additional controls. The observed values for the experimental coefficient of variation (CV\%) were low, indicating that experimental accuracy was high. The CV\% values ranged from $2.22 \%$ for $\mathrm{DH}$ to $17.58 \%$ for ARQ. There was a significant effect $(\mathrm{P}<0.01)$ among RILs for all traits. A significant effect was observed for the source of parental variation, except for DH and PROD traits. The comparison RILs versus Parents was significant $(\mathrm{P}<0.01)$ for the traits DFL, DH, PROD, and M100 but not for ARQ, H, or J (Table 2).

The averages of the 393 RILs for the seven traits were compared to the averages of the parents (Rudá and AND 277) using the Dunnett test at the 5\% probability level and were clustered into classes of equal or statistically different averages in relation to Rudá and AND 277 (Table 3). RILs showing transgressive segregation were observed for all traits except M100. For DFL, 37 RILs were observed with values exceeding Rudá (55.33 days); these DFL values ranged from 61.67 days (UFV-RA-033) to 81.00 days (UFVRA-277). However, none of the RILs presented a statistically lower average than the AND 277 parent, which had a DFL of 42.67 days. With respect to DH, 134 RILs exceeded Rudá (97.33 days). The RILs UFV-RA-360 and UFV-RA-277 showed the greatest DH, with 
cycles of 117 and 116 days, respectively. Twelve RILs fell below that of the AND 277 parent (96 days) and had cycles of 90 days.

For ARQ, the RILs UFV-RA-127 and UFV-RA-030 had grade 5.0 and 4.5, respectively; these values were statistically higher than that of Rudá (3.17). Eight RILs had a grade lower than that of AND 277 (2.33). None of the RILs were superior to Rudá $(4652.38 \mathrm{~kg} / \mathrm{ha})$ regarding PROD. Indeed, 298 RILs produced less than the AND 277 parent (4495.24 kg/ha); RIL UFV-RA-135 (423.81 kg/ha) and RIL UFV-RA-277 (395.24 $\mathrm{kg} / \mathrm{ha}$ ) had the lowest yields.

Table 2. Summary of analysis of variance and estimates for the coefficient of variation (CV\%), average RIL ( $\mu$ RILs), parents' average ( $\mu$ Parents), and heritability on average $\left(\mathrm{H}^{2}\right)$ for various traits evaluated in the trial of morphoagronomic characterization of RILs (Rudá x AND 277). Coimbra, MG, winter 2012.

\begin{tabular}{l|c|c|c|c|c|c|c|c}
\hline \multirow{2}{*}{ SV } & d.f. & \multicolumn{7}{c}{ Mean square $^{1}$} \\
\cline { 3 - 10 } & & DFL & DH & ARQ & PROD & H & J & M100 \\
\hline Block & 2 & 164.57 & 45.23 & 7.17 & $12,313,995.90$ & 0.0067 & 0.019 & 70.67 \\
\hline Treatments & 394 & 156.50 & 81.97 & 1.31 & $1,971,300.42$ & 0.0089 & 0.041 & 95.58 \\
\hline RILs & 392 & $156.47^{* *}$ & $82.16^{* *}$ & $1.32^{* *}$ & $1,935,032.23^{* *}$ & $0.0089^{* *}$ & $0.041^{* *}$ & $89.21^{* *}$ \\
\hline Parents (Te) & 1 & $240.67^{* *}$ & $2.67^{\text {ns }}$ & $1.04^{*}$ & $37,040.82^{\text {ns }}$ & $0.0136^{* *}$ & $0.235^{* *}$ & $2003.27^{* *}$ \\
\hline RILs vs Te & 1 & $86.89^{* *}$ & $88.48^{* *}$ & $0.012^{\text {ns }}$ & $18,122,690.18^{* *}$ & $0.0021^{\text {ns }}$ & $0.0002^{\text {ns }}$ & $689.06^{* *}$ \\
\hline Error & 788 & 6.39 & 4.99 & 0.23 & $210,563.99$ & 0.0011 & 0.0032 & 2.59 \\
\hline Efficiency lattice (\%) & & 100.23 & 101.64 & 100.83 & 105.16 & 102.21 & 101.38 & 101.51 \\
\hline CV\% & & 4.79 & 2.22 & 17.58 & 16.16 & 4.52 & 3.34 & 6.5 \\
\hline$\mu$ RILs & & 52.82 & 100.52 & 2.70 & 2831.45 & 0.75 & 1.69 & 24.72 \\
\hline$\mu$ Parents & & 49 & 96.67 & 2.75 & 4573.81 & 0.77 & 1.68 & 35.46 \\
\hline $\mathrm{H}^{2 \%}$ & & 95.91 & 93.93 & 82.81 & 89.12 & 87.27 & 92.23 & 97.09 \\
\hline
\end{tabular}

****Significant at 1 and $5 \%$ probability, respectively, by $\mathrm{F}$ test; $\mathrm{ns}=$ not significant. ${ }^{1} \mathrm{DFL}$ : number of days to flowering; DH: number of days until the harvest; ARQ: plant architecture; PROD: grain productivity in $\mathrm{kg} / \mathrm{ha} ; \mathrm{H}$ : degree of flattening; J: shape of seed; M100: mass of 100 seeds in gram.

For the degree of H, three RILs (UFV-RA-035, UFV-RA-107, and UFV-RA-210) showed higher values than AND 277 (0.81), with a range from 0.90 to 0.92. Genotypes with $\mathrm{H}$ values equal to or greater than 0.80 are classified as possessing 'full' type seeds. Nine RILs had $\mathrm{H}$ values ranging from 0.55 to 0.64 , which were lower than Rudá $(0.72$, intermediate type); these beans are classified as 'flat' $(\leq 0.69)$.

The AND 277 parental cultivar had an average value of 1.88 for $\mathrm{J}$ and was therefore classified as reniform type. Only RIL UFV-RA-365 had a significantly higher value (2.02); this was classified as long reniform type. By contrast, RIL UFV-RA-168 had a J value of 1.32 and was classified as spherical type; this was the only RIL that had a J value significantly lower than Rudá ( $\mathrm{J}=1.48$, elliptical type). None of the RILs had an M100 higher than that of AND 277 (53.73 g) or lower than that of Rudá (17.19 g). Most of the RILs (293) showed intermediate values, while 100 were not statistically different to Rudá.

The results of the seven traits evaluated in the 393 RILs and their parents were analyzed using the Scott-Knott test for clusters (Table 4). M100 and DFL formed the largest number of clusters, 10 and 9, respectively. PROD and ARQ contributed to the lowest number of clusters. 
We also used the Tocher agglomerative method and found that 10 clusters of RILs were formed based on a Mahalanobis generalized distance matrix (Table 5). Rudá was included in cluster III along with other seven RILs, whereas AND 277 was separate from the RIL clusters and was the only member of cluster XI.

Table 3. Clustering of RILs (Rudá x AND 277) into different classes of equal or statistically different averages for Rudá and AND 277 parents, by the Dunnett test, for the seven agronomic traits. Coimbra, MG, winter 2012.

\begin{tabular}{|c|c|c|c|c|c|c|c|c|}
\hline \multirow[t]{3}{*}{ Traits $^{1}$} & \multicolumn{6}{|c|}{ Number of RILs by class } & \multicolumn{2}{|c|}{ Parents average } \\
\hline & \multicolumn{3}{|c|}{ Equal $^{2}$} & \multicolumn{3}{|c|}{ Diferent $^{3}$} & \multirow[t]{2}{*}{ AND 277 (A) } & \multirow[t]{2}{*}{ Rudá (B) } \\
\hline & $\mathrm{A}$ & $\mathrm{B}$ & $\mathrm{AB}$ & Bigger & Less & Between A-B & & \\
\hline DFL & 127 & 221 & 0 & $37>(B)$ & $0<(\mathrm{A})$ & 8 & 42.67 & 55.33 \\
\hline DH & 7 & 44 & 196 & $134>(B)$ & $12<(\mathrm{A})$ & 0 & 96.00 & 97.33 \\
\hline ARQ & 63 & 53 & 267 & $2>(B)$ & $8<(\mathrm{A})$ & 0 & 2.33 & 3.17 \\
\hline PROD & 32 & 0 & 63 & $0>(\mathrm{B})$ & $298<(\mathrm{A})$ & 0 & 4495.24 & 4652.38 \\
\hline $\mathrm{H}$ & 55 & 140 & 186 & $3>(A)$ & $9<(\mathrm{B})$ & 0 & 0.81 & 0.72 \\
\hline $\mathrm{J}$ & 127 & 105 & 0 & $1>(\mathrm{A})$ & $1<(\mathrm{B})$ & 159 & 1.88 & 1.48 \\
\hline M100 & 0 & 100 & 0 & $0>(\mathrm{A})$ & $0<(\mathrm{B})$ & 293 & 53.73 & 17.19 \\
\hline
\end{tabular}

${ }^{1}$ DFL: number of days to flowering; DH: number of days until the harvest; ARQ: plant architecture; PROD: grain productivity in $\mathrm{kg} / \mathrm{ha}$; $\mathrm{H}$ : degree of flattening; $\mathrm{J}$ : shape of seed; M100: mass of 100 seeds in gram. ${ }^{2}$ Equal: class strains with statistically equivalent to the average parent AND 277 (A), Rudá (B) and either simultaneously (AB) (Dunnett test, $\mathrm{P}<5 \%$ ). ${ }^{3}$ Diferent: class of strains with higher average (Bigger) than the parent with the highest average; class of strains with lower average (Less) than the parent with the lowest average; and class of strains with an average between the average of the parents (Between $\mathrm{AB}$ ) (Dunnett test, $\mathrm{P}<5 \%$ ).

Table 4. Clustering of RILs (Rudá x AND 277) and parents, by the Skott-Knott test, for the various traits evaluated in morphoagronomic characterization trials and total of clusters for traits. Coimbra, MG, winter 2012.

\begin{tabular}{|c|c|c|c|c|c|c|c|c|c|c|c|c|c|}
\hline \multirow[t]{3}{*}{ Traits $^{1}$} & \multicolumn{13}{|c|}{ Average clusters } \\
\hline & A & B & $\mathrm{C}$ & $\mathrm{D}$ & $\mathrm{E}$ & $F$ & $\mathrm{G}$ & $\mathrm{H}$ & $\mathrm{I}$ & $\mathrm{J}$ & $\mathrm{K}$ & $\mathrm{L}$ & \\
\hline & \multicolumn{12}{|c|}{ Number of RILs by cluster ${ }^{2}$} & Total \\
\hline M100 & $A n$ & 5 & 7 & 14 & 11 & 51 & 57 & 78 & 74 & 63 & $24^{R u}$ & 9 & 11 \\
\hline$\overline{\mathrm{DFL}}$ & 6 & 10 & 10 & 60 & $108^{R u}$ & 52 & 47 & 54 & $46^{A n}$ & & & & 9 \\
\hline DH & 11 & 45 & 78 & 72 & 56 & $71^{A n R u}$ & 41 & 19 & & & & & 8 \\
\hline $\mathrm{J}$ & 10 & $37^{A n}$ & 129 & 139 & 62 & $13^{R u}$ & 3 & & & & & & 7 \\
\hline$\overline{\mathrm{H}}$ & 11 & $33^{A n}$ & 153 & $140^{R u}$ & 47 & 9 & & & & & & & 6 \\
\hline PROD & $18^{A n R u}$ & 56 & 166 & 113 & 26 & 14 & & & & & & & 6 \\
\hline ARQ & 76 & $173^{R u}$ & $89^{A n}$ & 55 & & & & & & & & & 4 \\
\hline
\end{tabular}

${ }^{1} \mathrm{M} 100$ : mass of 100 seeds in gram; DFL: number of days to flowering; DH: number of days until the harvest; J: shape of seed; H: degree of flattening; PROD: grain productivity in $\mathrm{kg} / \mathrm{ha}$; ARQ: plant architecture. ${ }^{2}$ Strains within the same cluster (same letter of the alphabet) are homogeneous with each other at 5\% probability by Skott-Knott test. ${ }^{A n, R u}$ : presence of parents AND 277 and Rudá, respectively, in Average clusters formed.

Assessment of the relative contribution of each of the seven traits for the genetic dissimilarity among the RILs (Singh, 1981) is summarized in Table 6. The traits that contributed most to genetic dissimilarity among RILs were M100 (34.58\%) and DFL (19.54\%) and those that contributed least were PROD (6.95\%) and ARQ (5.28\%).

Genetics and Molecular Research 15 (3): gmr.15038112 
Table 5. Clustering of 393 RILs (Rudá x AND 277) and parents, by Tocher agglomerative method, based on the Mahalanobis generalized distance indexes estimated using morphoagronomic traits. Coimbra, MG, winter 2012.

\begin{tabular}{|c|c|c|}
\hline Cluster & $\mathrm{N}^{1}$ & Rudá x AND 277 RILs (ID Code: UFV-RA) \\
\hline $\bar{I}$ & 329 & 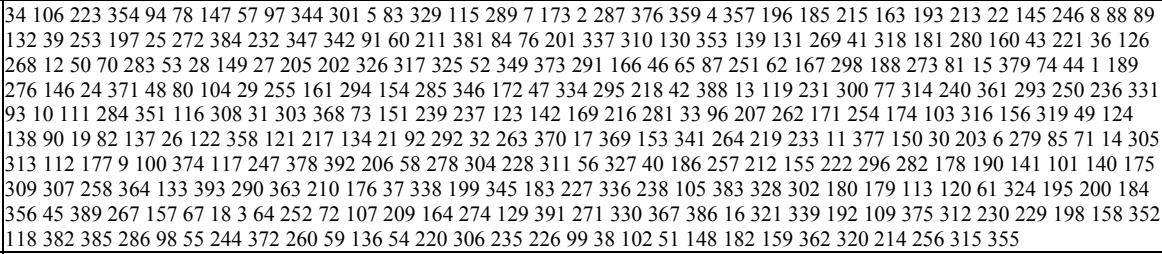 \\
\hline II & 16 & 95162143108245288114202663333502046913522535 \\
\hline III & 7 & 66265348323380168187 Rudá \\
\hline IV & 2 & 297387 \\
\hline $\mathrm{V}$ & 31 & 15219436627524120812533275248335249299234242340261224170343322365390128681917924386165259 \\
\hline$\overline{\mathrm{VI}}$ & 3 & 2311063 \\
\hline VII & 2 & 144270 \\
\hline $\begin{array}{llll}\mathrm{VIII} \\
\end{array}$ & 1 & 127 \\
\hline$\underline{\mathrm{IX}}$ & 1 & 360 \\
\hline $\bar{X}$ & 1 & 277 \\
\hline $\mathrm{XI}$ & - & AND 277 \\
\hline
\end{tabular}

${ }^{1}$ Number of RILs in each cluster. ${ }^{2}$ RILs identification code: UFV-RA-No. sequential. In this table, were presented just sequential numbers.

Table 6. Relative contribution of the various traits evaluated in the trial of morphoagronomic characterization of RILs (Rudá x AND 277) for genetic dissimilarity, and number of average cluster formed for each trait based on the Skott Knott test. Coimbra, MG, winter 2012

\begin{tabular}{l|c|c|c}
\hline Traits $^{1}$ & S.J. $^{2}$ & Value (\%) & Clusters (Skott-Knott) $^{3}$ \\
\hline M100 & $1,895,537.02$ & 34.58 & 10 \\
\hline DFL & $1,070,903.85$ & 19.54 & 9 \\
\hline DH & $724,140.51$ & 13.21 & 8 \\
\hline J & $674,584.83$ & 12.31 & 7 \\
\hline PROD & $445,516.09$ & 8.13 & 6 \\
\hline ARQ & $380,992.23$ & 6.95 & 6 \\
\hline
\end{tabular}

${ }^{1} \mathrm{M} 100$ : mass of 100 seeds in gram; DFL: number of days to flowering; DH: number of days until the harvest; J: shape of seed; $\mathrm{H}$ : degree of flattening; PROD: grain productivity in $\mathrm{kg} / \mathrm{ha}$; ARQ: plant architecture. ${ }^{2}$ Singh estimate: total distance corresponding to each trait. ${ }^{3}$ Number of average clusters statistically different ( $5 \%$ probability) based on Scott-Knott test.

\section{DISCUSSION}

The CV\% vaalues observed for the evaluated traits (Table 2) were close to those reported by Ribeiro et al. (2009) in their study using 185 RILs from 11 different populations. According to Ramalho et al. (2012a), low coefficients of variation are of interest because they provide more accurate estimates of genetic parameters.

The significant effects among the RILs for all traits (Table 2) indicated the existence of extensive genetic variability in this RIL population derived from Rudá and AND 277. This variability is essential for genetic mapping and QTL identification (Faleiro et al., 2003). Other investigators also have observed significant differences in the traits DFL, DH, ARQ, PROD, H, J, and M100 in common bean. Blair et al. (2012) reported significant effects for DFL, DH, 
PROD, and M100, in 113 RILs derived from parents belonging to the same Mesoamerican gene pool. Faleiro et al. (2003) investigated 154 RILs derived from a cross between Ouro Negro and Rudá (both from the Mesoamerican gene pool) and found significant effects for the traits DFL, DH, and M100. Similarly, Beattie et al. (2003) reported significant effects for DH and PROD traits in 110 RILs derived from a cross between WO3391 and OAC Speedvale evaluated in different years and locations.

The genetic divergence of Rudá (Mesoamerican) and AND 277 (Andean) is expected as they belong to different gene pools. This divergence is confirmed by the significance of the parental sources of variation for most of the evaluated traits (Table 2). Even in the case of DH and PROD, where the difference between parents was not significant, there was significant difference among the RILs in relation to the source of variation indicating the presence of some difference between the parents. This may be due to the complementarity of genes from Rudá and AND 277 parents in the control of DH and PROD.

The comparison RILs versus Parents showed the presence of a significant difference (Table 2) indicating that the average of the RILs differed from those of the parents. For DFL and DH, the RIL average was greater than those of the parents, whereas for PROD and M100, the parental average surpassed that of the RILs. No difference between the averages of the parents and RILs is expected in the absence of epistasis (Johnson and Gepts, 2002). Thus, our results indicate the occurrence of epistatic interactions of the type additive $\mathrm{x}$ additive for the traits DFL, DH, PROD, and M100. It is worth noting that genetic mismatch effects have previously been observed in crosses involving Andean and Mesoamerican bean cultivars (Koinange and Gepts, 1992; Singh and Molina, 1996; Johnson and Gepts, 1999). These effects are manifested primarily by cycle related traits and productivity (see discussion by Johnson and Gepts, 1999, 2002). However, Voysest (2000) presented a hypothesis for a Mesoamerican and Andean origin for the lineage AND 277 on the basis of the cross compatibility between this lineage and Mesoamerican cultivars. In an allelism study including AND 277, Caixeta et al. (2005) suggested that this common bean line harbors three angular leaf spot resistance genes $\left(P h g-2^{2}, P h g-3^{2}, P h g-4^{2}\right)$ from a Mesoamerican origin.

Transgressive segregation, i.e., RILs with averages higher or lower than those of the parents, were observed for all traits except for M100 (Table 3). These results are one more indication of the high variability of the RIL population obtained from the cross between Rudá and AND 277. According to Ramalho et al. (2012b), transgressive segregation in the $\mathrm{F}_{2}$ generation to give individuals with performance outside the limits of the parents is due to by genotypic complementarity of the parents. It is worth noting that each RIL in this study was derived by SSD from a single individual of the $\mathrm{F}_{2}$ generation.

Bean cultivars with a cycle less than 72 days are considered "early cycle", while those with cycles greater than 90 days are considered "late cycle". Most cultivars used by Brazilian bean growers are intermediate with a 90-day cycle (Buratto et al., 2007). The use of early cultivars can be beneficial for rational use of land as they allow the grower the opportunity to choose the most suitable time for sowing and harvesting and, consequently, to grow successional crops. It is worth noting that RILs whose flowering periods and cycles are too long in relation to the parents (Table 3 ) or to conventional bean culture may be associated with the genetic incompatibility problems that can occur in populations produced by parents of very different gene pools.

Plants with an erect architecture combined with a high position of the first pod are desirable traits for mechanical harvesting, reducing losses, and increasing the quality of the

Genetics and Molecular Research 15 (3): gmr.15038112 
harvested beans. In addition, these traits facilitate growing practices and reduce the occurrence of diseases such as white mold (Santos and Vencovsky, 2004).

The search for genotypes with an erect architecture is a priority for breeders of common beans. This trait is complex, dependent on several others, and is affected by the environment. The diameter of the hypocotyl, the insertion angle of the branches, and the height of plants at harvest are the main determinants of the architecture of bean plants (Moura et al., 2013). With regard to selecting more erect plants, Moura et al. (2013) reported that hypocotyl diameter is highly correlated with architecture and provided higher precision and greater ease in the assessment. Silva et al. (2013) and Rocha et al. (2012) found a predominance of additive effects on the genetic control of hypocotyl diameter and architecture of common bean plants. Rocha et al. (2012) additionally reported that the correlation between hypocotyl diameter and architectural grade is due to the additive effects of pleiotropic genes.

The low productivity of some RILs, such as UFV-RA-135 and UFV-RA-227, might be associated with genetic incompatibility problems that commonly occur in populations derived from crosses of parents from different gene pools. The non-occurrence of transgressive segregation for the M100 trait could be explained by the fact that AND 277 and Rudá showed the largest and the smallest genotypic values for this trait, respectively. Generally, the occurrence of transgressive segregation is indicative of gene complementarity between the parents (Rudá and AND 277), an important consideration in identifying RILs with high variability.

The Scott-Knott test showed clusters for all traits (Table 4) confirming the existence of variability among the RILs. In agreement with our observations, previous studies have reported that the weight of beans was the main trait involved in discriminating genotypes among common bean plants (Benin et al., 2002; Ribeiro et al., 2009).

The separation of the 393 RILs into 10 clusters by the Tocher analysis (Table 5) also confirmed the high variability within the population. The inclusion of the parental types in different clusters is another factor that supported the presence of genetic diversity, as well as the effectiveness of the traits for evaluating the presence of genetic variability in the 393 RILs. Lima et al. (2012) examined 22 common bean traits in 100 accessions belonging to the Andean and Mesoamerican gene pools, obtained from the UFV common bean germplasm bank, and showed these fell into eight clusters. Of the 22 traits evaluated by Lima et al. (2012), six match those used in this study: J, H, DFL, ARQ, PROD, and M100.

Sanglard et al. (2013), using a set of 126 SSR (simple sequence repeat) and 677 single nucleotide polymorphism (SNP) markers, estimated the genetic distance between Rudá and AND 277 as 78.6 and 71.3\%, respectively. Cargnelutti Filho et al. (2008) also split an Andean cultivar and 12 other Mesoamerican cultivars by hierarchical and Tocher methods based on the Mahalanobis generalized distance matrix. Veloso et al. (2015) used molecular markers to assess genetic dissimilarity among cultivars and showed that the greatest difference belonged to the Black/Mesoamerican and Streaked/Andean types.

As in the present study, an evaluation of 13 genotypes (advanced lines and commercial cultivars) also detected that M100 was the trait that most contributed to the genetic dissimilarity in the common bean (Corrêa and Gonçalves, 2012). Similarly, Benin et al. (2002) reported that the mass of thousand beans was the most important trait for the genetic dissimilarity in bean plant genotypes.

With regard to dissimilarity among RILs, the Scott-Knott analysis found a coincidence between the more important traits (M100 and DFL) and the less important traits (PROD and ARQ) in the numbers of clusters in which they were involved: M100 and DFL participated in 10 and 9

Genetics and Molecular Research 15 (3): gmr.15038112 
clusters, while PROD and ARQ were present in six and four clusters, respectively (Table 6).

It is noteworthy that the present population of RILs is adapted to the soil and climate conditions of Brazil. This facilitates their maintenance and the exchange of seeds in this country, as well as large-scale field phenotyping.

We conclude that from the phenotypic characterization performed in this study, the 393 RILs derived from a cross between Rudá and AND 277 exhibited significant genetic variability and are thus promising materials for genetic mapping studies and the detection of QTLs. This population will be used by the common bean program conducted by UFV, Embrapa and partners for the development of a core genetic map for $P$. vulgaris that is both saturated with markers and has accurate estimates of recombination frequencies.

\section{Conflicts of interest}

The authors declare no conflict of interest.

\section{ACKNOWLEDGMENTS}

Research supported by grants from CNPq (Conselho Nacional de Desenvolvimento Científico e Tecnológico) and FAPEMIG (Fundação de Amparo à Pesquisa do Estado de Minas Gerais), Brazilian Government.

\section{REFERENCES}

Aggarwal VD, Pastor-Corrales MA, Chirwa R and Buruchara RA (2004). Andean beans (Phaseolus vulgaris) with resistance to the angular leaf spot pathogen (Phaeoisariopsis griseola) in Southern and Eastern Africa. Euphytica 136: 201-210. http://dx.doi.org/10.1023/B:EUPH.0000030678.12073.a9

Arumugahathan K and Earle ED (1991). Nuclear DNA content of some important plant species. Plant Mol. Biol. Report. 9: 208-218. http://dx.doi.org/10.1007/BF02672069

Barros EG and Souza TLPO (2012). Biotecnologia aplicada à Agropecuária. In: Biotecnologia aplicada à cultura do feijoeiro (Cançado GMA, Londe LN, eds.). Empresa de Pesquisa Agropecuária de Minas Gerais, Caldas, 60-66.

Beattie AD, Larsen J, Michaels TE and Pauls KP (2003). Mapping quantitative trait loci for a common bean (Phaseolus vulgaris L.) ideotype. Genome 46: 411-422. http://dx.doi.org/10.1139/g03-015

Benin G, Carvalho FIF, Assmann IC, Cigolini J, et al. (2002). Identificação da dissimilaridade genética entre genótipos de feijoeiro comum (Phaseolus vulgaris L.) do grupo preto. Rev. Bras. Agrocienc 8: 179-184.

Blair MW, Pedraza F, Buendia HF, Gaitán-Solís E, et al. (2003). Development of a genome-wide anchored microsatellite map for common bean (Phaseolus vulgaris L.). Theor. Appl. Genet. 107: 1362-1374. http://dx.doi.org/10.1007/ s00122-003-1398-6

Blair MW, Galeano CH, Tovar E, Muñoz Torres MC, et al. (2012). Development of a Mesoamerican intra-genepool genetic map for quantitative trait loci detection in a drought tolerant $\times$ susceptible common bean (Phaseolus vulgaris L.) cross. Mol. Breed. 29: 71-88. http://dx.doi.org/10.1007/s11032-010-9527-9

Buratto JS, Moda-Cirino V, Fonseca Júnior NS, Prete CEC, et al. (2007). Adaptabilidade e estabilidade produtiva em genótipos precoces de feijão no estado do Paraná. Semin. Cienc. Agrar. 28: 373-380. http://dx.doi.org/10.5433/1679$\underline{0359.2007 \mathrm{v} 28 \mathrm{n} 3 \mathrm{p} 373}$

Caixeta ET, Borém A, Alzate-Marin AL, Fagundes AS, et al. (2005). Allelic relationships for genes that confer resistance to angular leaf spot in common bean. Euphytica 145: 237-245. http://dx.doi.org/10.1007/s10681-005-1258-3

Collard BCY, Jahufer MZZ, Brouwer JB and Pang ECK (2005). An introduction to markers, quantitative trait loci (QTL) mapping and marker-assisted selection for crop improvement: The basic concepts. Euphytica 142: 169-196. http:// dx.doi.org/10.1007/s10681-005-1681-5

Collicchio E, Ramalho MAP and Abreu AFB (1997). Associação entre o porte da planta do feijoeiro e o tamanho dos grãos. Pesq. Agropec. Bras. 32: 297-304.

Corrêa AM and Gonçalves MC (2012). Diversidade genética em genótipos feijão-comum cultivados em Mato Grosso do

Genetics and Molecular Research 15 (3): gmr.15038112 
Sul. Ceres 59: 206-212. http://dx.doi.org/10.1590/S0034-737X2012000200009

Cruz CD (2013). GENES - a software package for analysis in experimental statistics and quantitative genetics. Acta Scientiarum 35: 271-276.

Embrapa (2014). Empresa Brasileira de Pesquisa Agropecuária. Available at [http://www.agencia.cnptia.embrapa.br/ gestor/feijao/arvore/CONTAG01_106_243200313236.html]. Accessed December 12, 2014.

Faleiro FG, Schuster I, Ragagnin VA, Cruz CD, et al. (2003). Caracterização de linhagens endogâmicas recombinantes e mapeamento de locos de características quantitativas associados ao ciclo e produtividade do feijoeiro-comum. Pesq. Agropec. Bras. 38: 1387-1397. http://dx.doi.org/10.1590/S0100-204X2003001200005

Cargnelutti Filho AC, Ribeiro ND, Reis RCP, Souza JR, et al. (2008). Comparação de métodos de agrupamento para o estudo da divergência genética em cultivares de feijão. Cienc. Rural 38: 2138-2145. http://dx.doi.org/10.1590/ $\underline{\mathrm{S} 0103-84782008000800008}$

Freyre R, Skroch PW, Geffroy V, Adam-Blondon A, et al. (1998). Towards an integrated linkage map of common bean. 4. Development of a core linkage map and alignment of RFLP maps. Theor. Appl. Genet. 97: 847-856. http://dx.doi. org $/ 10.1007 / \mathrm{s} 001220050964$

Galeano CH, Fernández AC, Gómez M and Blair MW (2009). Single strand conformation polymorphism based SNP and Indel markers for genetic mapping and synteny analysis of common bean (Phaseolus vulgaris L.). BMC Genomics 10: 629. http://dx.doi.org/10.1186/1471-2164-10-629

Grisi MCM, Blair MW, Gepts P, Brondani C, et al. (2007). Genetic mapping of a new set of microsatellite markers in a reference common bean (Phaseolus vulgaris) population BAT93 x Jalo EEP558. Genet. Mol. Res. 6: 691-706.

Johnson CW and Gepts P (2002). The role of epistasis in controlling seed yield and other agronomic traits in an Andean x Mesoamerican cross of common bean (Phaseolus vulgaris L.). Euphytica 125: 69-79. http://dx.doi. org/10.1023/A:1015775822132

Johnson W and Gepts P(1999). Segregation for performance in recombinant inbred populations resulting from inter-gene pool crosses of common bean (Phaseolus vulgaris L). Euphytica 106: 45-56. http://dx.doi.org/10.1023/A:1003541201923

Koinange EMK and Gepts P (1992). Hybrid weakness in wild Phaseolus vulgaris L. J. Hered. 83: 135-139.

Lamprecht H (1961). Weitere kopplungsstudien an Phaseolus vulgaris mit einer über die koppelungsgruppens. Agr. Hort. Genet. 9: 319-332.

Lima MSD, Carneiro JEDS, Carneiro PCS, Pereira CS, et al. (2012). Characterization of genetic variability among common bean genotypes by morphological descriptors. Crop Breed. Appl. Biotechnol. 12: 76-84. http://dx.doi. org/10.1590/S1984-70332012000100010

MAPA (2012). Ministério da Agricultura Pecuária e Abastecimento. Available at [http://www.agricultura.gov.br/vegetal/ registros-autorizacoes/protecao-cultivares/formularios-protecao-cultivares]. Accessed August 15, 2012.

Moura MM, Carneiro PCS, Carneiro JES and Curz CD (2013). Potencial de características na avaliação da arquitetura de plantas de feijão. Pesq. Agropec. Bras. 48: 417-425. http://dx.doi.org/10.1590/S0100-204X2013000400010

Ramalho MAP, Ferreira DF and Oliveira AC (2012a). Experimentação em genética e melhoramento de plantas. 3rd edn. Editora UFLA, Lavras.

Ramalho MAP, Santos JB, Pinto CABP, Souza EA, et al. (2012b). Genética na agropecuária. 5th edn. Editora UFLA, Lavras.

Ribeiro EH, Pereira MG, Coelho KS and Júnior SPF (2009). Estimativas de parâmetros genéticos e seleção de linhagens endogâmicas recombinantes de feijoeiro comum (Phaseolus vulgaris L.). Ceres 56: 580-590.

Rocha GS, Pereira LPL, Carneiro PCS, Paula TJ, Junior., et al. (2012). Common bean breeding for resistance to anthracnose and angular leaf spot assisted by SCAR molecular markers. Crop Breed. Appl. Biotechnol. 12: 34-42. http://dx.doi. org/10.1590/S1984-70332012000100005

Sanglard DA, Mafra VS, Ribeiro CAG, Silva LC, et al. (2013). Rudá x AND 277 RILs: a potential new core mapping population for common bean. Annu. Rep. Bean Improv. Coop. 56: 23-24.

Santos JB and Vencovsky R (2004). Controle genético de alguns componentes do porte da planta em feijoeiro. Pesq. Agropec. Bras. 21: 957-963.

Schuster I and Cruz CD (2004). Estatística genômica aplicada a populações derivadas de cruzamentos controlados. 1st edn. Editora UFV, Viçosa.

Semagn K, Bjornstad A and Ndjiondjop MN (2006). Principles, requirements and prospects of genetic mapping in plants. Afr. J. Biotechnol. 5: 2569-2587.

Silva LC, Cruz CD, Moreira MA and Barros EG (2007). Simulation of population size and genome saturation level for genetic mapping of recombinant inbred lines (RILs). Genet. Mol. Biol. 30: 1101-1108. http://dx.doi.org/10.1590/ $\underline{\text { S1415-47572007000600013 }}$

Silva VMP, Menezes Júnior JAN, Carneiro PCS, Carneiro JES, et al. (2013). Genetic improvement of plant architecture in the common bean. Genet. Mol. Res. 12: 3093-3102. http://dx.doi.org/10.4238/2013.January.30.8

Singh D (1981). The relative importance of characters affecting genetic divergence. Indian J. Genet. Plant Breed. 41 :

Genetics and Molecular Research 15 (3): gmr.15038112 
237-245.

Singh S and Molina A (1996). Inheritance of crippled trifoliolate leaves occurring in interracial crosses of common bean and its relationship with hybrid dwarfism. J. Hered. 87: 464-469. http://dx.doi.org/10.1093/oxfordjournals.jhered. a023039

Veloso JS, Silva W, Pinheiro LR, Dos Santos JB, et al. (2015). Genetic divergence of common bean cultivars. Genet. Mol. Res. 14: 11281-11291. http://dx.doi.org/10.4238/2015.September.22.22

Voysest OV (2000). Mejoramiento Genético Del Frijol (Phaseolus vulgaris L.): legado de variedades de América Latina 1930-1999. CIpAT, Cali.

Genetics and Molecular Research 15 (3): gmr.15038112 